http://dx.doi.org/10.15407/ukrbotj72.02.135

\title{
I.В. ВАНТЮХ
}

Інститут ботаніки імені М.Г. Холодного НАН України

вул. Терещенківська, 2, м. Київ, 01601, Україна

igorvan@mail.ru

\section{MOНITOРИНГ РЕСУРСІВ ARNICA MONTANA (ASTERACEAE) HА ТЕРИТОРIÏ УКРАÏHСЬКИХ KАРПАТ}

Вантюх I.B. Моніторинг ресурсів Arnica montana (Asteraceae) на території Українських Карпат.Укр. ботан. журн.- 2015. - 72(2): 135-143.

Подано результати п'ятирічних спостережень за динамікою структури та ресурсною значущістю ценопопуляцій Arnica montana L. на семи моніторингових площах у різних регіонах Карпат. Вивчено вплив сінокосіння та пасовищного навантаження на стан і динаміку іiі ресурсів. Встановлено, що найбільш вираженим лімітуючим фактором для ресурсної значущості ценопопуляцій $A$. montana $є$ пасовищне навантаження на іiі біотопи. В умовах обмеженого антропогенного навантаження зміни у віковій структурі популяцій $A$. montana та іiі ресурсній значущості відбуваються повільно і визначаються ступенем ценотичної конкуренції.

Ключов і слов в: Arnica montana, моніторинг, ресурси, антропогенний вплив

\section{Ветуп}

3'ясування стану та тенденцій зміни ресурсів особливо цінних видів рослин в умовах трансформованого середовища - одне з головних завдань ботанічного ресурсознавства. Для забезпечення сталого використання природних фіторесурсів і їхнього збереження важливо дослідити залежність стану та динаміки популяцій і ресурсів сировинно цінних рослин від впливу негативних чинників (Kahmen, Roschlod, 2000; Hamilton et al., 2006).

Одним із найважливіших сировинних видів лікарських рослин Українських Карпат є Arnica montana L., яка широко використовується в народній та офіційній медицині країн Європи, зокрема в Україні. У зв'язку з посиленням тенденції до скорочення популяцій $A$. montana по всьому ареалу та складності ії культивування цьому ендемічному європейському виду приділяється велика увага в різних країнах (Kathe et al., 2003; Kathe, 2006). Основною загрозою для популяцій A. montana в країнах Північної, Західної та Центральної Європи є надмірний антропогенний вплив на іiі оселища, зворотні масштабні демутаційні процеси, які супроводжуються заростанням вторинних лук лісовою або чагарниковою рослинністю, інсуляризація популяцій і фрагментація середовищ зростання, що збіднює генетичну різноманітність іiі популяцій, нерегульований збір сировини (Parolo et al., 2008; Kobiv, 2014). Arnica montana занесена до Червоного списку МСОП (Least Concern, LC) як вид, по-

(C) I.B. BAHTЮХ, 2015 пуляції котрого в дикій природі перебувають у стані низького рівня ризику «IUCN Red List» [http:// www.iucnredlist.org]. До останнього видання «Червоної книги України» (2009) цей вид не занесено.

Завдання нашого дослідження - з'ясувати стан і динаміку розвитку популяцій та формування ресурсів $A$. montana за умов антропогенного навантаження чи за його відсутності в Українських Карпатах.

\section{Об'єкти та методи досліджень}

Матеріали зібрано під час польових досліджень протягом 2010-2014 рр. Облік і моніторинг ресурсів A. montana здійснювався з використанням загальноприйнятих методів ботанічного ресурсознавства (облікових площ і ділянок, а також модельних екземплярів (Minarchenko et al., 2008)). Для спостережень за динамікою популяцій і ресурсів A. montana в різних частинах Українських Карпат у 2010 р. було закладено сім постійних моніторингових площ у діапазоні висот 760-1200 м над р.м. (таблиця), на кожній із яких - по 10 (11) системно розміщених облікових ділянок, де щорічно реєстрували ресурсозначимі показники виду. Моніторингові площі заклали на відкритих схилах різної експозиції, крутизною 5-45 \%, з урахуванням різного ступеня антропогенного навантаження на фітоценози та за його відсутності (таблиця). Дані про початок цвітіння A. montana та ступінь антропогенного навантаження на моніторингові площі отримували від працівників НПП «Синевир», Карпатського біосферного заповідника, а також безпосередньо від місцевого населення. 
На кожній моніторинговій площі (МП) у перший рік іiі існування здійснювали повний геоботанічний опис, а потім щорічно оцінювали рясність iii флористичного складу; на облікових ділянках визначали проективне покриття A. montana, чисельність і щільність особин різних вікових груп, висоту рослин, кількість пагонів і суцвіть на пагоні, щільність запасу сировини (суцвіть), аналізували особливості антропогенного навантаження на оселища. Для кількісних показників з'ясовували середнє арифметичне та його похибку. Достовірність відмінності середніх показників визначали за допомогою методів дисперсійного аналізу. Для кожної ценопопуляції оцінювали також повноту та симетричність онтогенетичних спектрів, а вікову структуру рослин $A$. montana визначали як проросток $(p)$, ювенільний $(j)$, імматурний $(i m)$, віргінільний $(v)$, генеративний $(g)$, субсенільний (ss) і сенільний (s) (Uranov, 1975; Rabotnov, 1988). Щільність запасу сировини встановлювали як добуток кількості суцвіть на середні показники маси одного суцвіття. Останні визначали як середнє 100 суцвіть, зібраних у 3-кратній повторності поза межами моніторингової площі. Зазначимо, що середні показники маси одного суцвіття на моніторингових площах майже не відрізнялися і становили $1,15 \pm 0,02$ г.

\section{Результати досліджень і їх обговорення}

На період початку моніторингу на МП № 1 пасовищне навантаження зросло майже удвічі порівняно з 2009 р. Станом на 6 червня 2010 року цепопуляція A. montana характеризувалася великою кількістю особин $\left(277 / 11 \mathrm{~m}^{2}\right)$, однак більшість із них були пошкоджені, частка генеративних особин незначна (таблиця), в окремих випадках складно було визначити їх на приналежність до певної вікової групи. Проективне покриття $A$. montana на моніторинговій площі в ущільненнях сягало $20 \%$, на відкритій ділянці - 3 \%, у середньому воно становило близько $7 \%$. На більшості генеративних пагонів (70\%) було сформоване лише одне суцвіття.

Дигресивні зміни рослинного покриву та ценопопуляції $A$. montana на МП №1 особливо чітко виявилися у 2011 р., оскільки надмірне пасовищне навантаження впродовж літа минулого року призвело до загибелі багатьох особин виду. Кількість рослин $A$. montana на облікових ділянках зменши- лася на $26 \%$, зокрема молодих і генеративних особин - більше ніж удвічі (таблиця).

Зниження пасовищного навантаження у 2011 р. позитивно позначилося на представленості та життєвості більшості видів різнотрав'я (станом на початок червня 2012 р.): зросло проективне покриття травостою, участь різнотрав'я в угрупованні, значно збільшилася кількість генеративних особин A. montana (таблиця). Упродовж 2013-2014 рр. пасовищне навантаження в межах моніторингової ділянки суттєво зменшилося, проективне покриття травостою збільшилося переважно за рахунок розростання різнотрав'я; побільшала також кількість особин A. montana, особливо молодшої вікової групи та генеративних пагонів. Збільшилися розміри листків вегетативних розеток виду, що позитивно позначилося на проективному покритті. Кількість суцвіть на облікових ділянках зросла майже вдвічі порівняно з 2010 р. і в 5 разів - із 2011. Такі зміни можна пояснити посиленим використанням дорослими рослинами ресурсів середовища й активним спрямуванням їх на генеративне розмноження в умовах стресу, що властиве багатьом видам трав'янистих рослин. На облікових ділянках суттєво збільшилася кількість генеративних пагонів із трьома суцвіттями, хоча на багатьох пагонах повноцінно розвинулися лише по два суцвіття. За нашими спостереженнями, недорозвинені суцвіття на генеративних пагонах A. montana 3'являються переважно за умов нестачі ресурсів середовища внаслідок пасовищного навантаження чи негативного впливу температурного режиму на початку вегетації. На моніторинговій площі відзначається тенденція відновлення рослинного покриву за умов зменшення пасовищного навантаження. Однак відновлення ценопопуляції $A$. montana відбувається, кількість особин молодшої вікової групи обмежена, активний розвиток конкурентоспроможних видів лімітує ресурси середовища, необхідні для їхнього розвитку (Kyjak, 2007). Велика частка вегетативних особин $A$. montana на МП №1 може забезпечити реалізацію іiі ресурсної значущості впродовж тривалого періоду за умови обмеженого пасовищного навантаження або його відсутності.

На МП №2 наявне систематичне антропогенне навантаження (сінокосіння 1-2 рази на рік і неконтрольований збір суцвіть $A$. montana). На площі виявлено 30 видів рослин, найрясніші з яких - це Festuca rubra L. (40\%), Nardus stricta L. (10\%), Vaccinium 


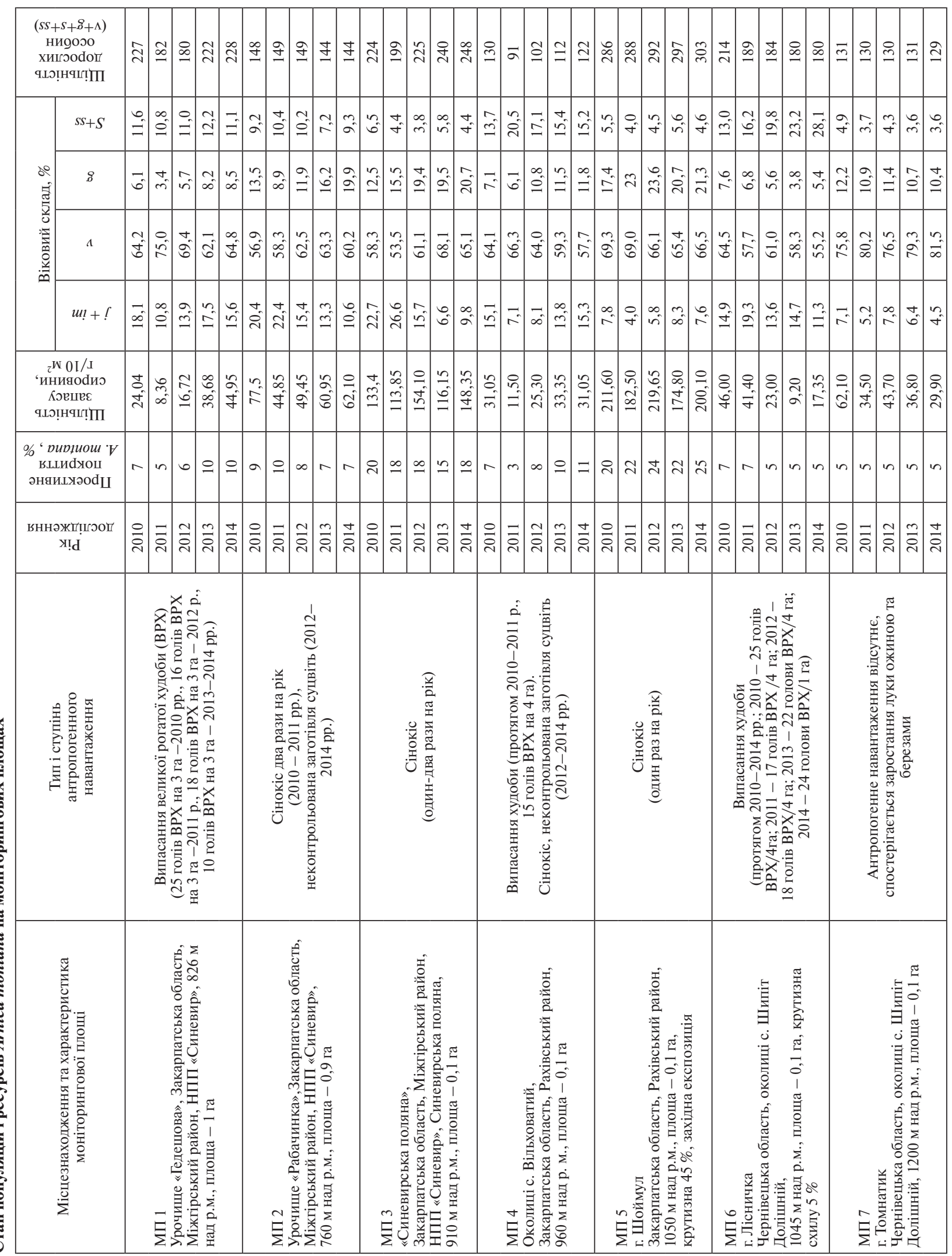


myrtilus L. (5\%) i Potentilla erecta (L.) Raeusch. (5\%); моховий ярус становить 10-15\%, зростають чотири молодих дерева Picea abies L. (три-чотирирічні). Проективне покриття трав'яно-чагарничкового ярусу варіює в межах 90-95\%. Ценопопуляція A. montana перебуває в задовільному стані. Базовий віковий спектр $A$. montana лівобічного типу з максимумом на віргінільній групі (таблиця). У базовому спектрі наявні всі онтогенетичні групи, віргінільні та молоді генеративні рослини становлять близько $77 \%$ (таблиця).

Особливістю досліджуваної ценопопуляції A. montana є обмежена представленість генеративних і сенільних особин, що є закономірним для популяцій цього виду в сформованих фітоценозах за умов слабкого антропогенного навантаження. Генеративні пагони здебільшого мають по три i більше суцвіть, що свідчить про здатність дорослих особин A. montana максимально використовувати ресурси середовища при досягненні ними певної вікової категорії навіть за умов ценотичної конкуренції. Початок цвітіння $A$. montana майже щорічно припадає тут на 4-6 червня.

Результати спостережень за змінами стану ценопопуляції виду впродовж наступного періоду свідчать про поступове збільшення кількості генеративних особин (переважно за рахунок таких з одним суцвіттям), проте загальна кількість суцвіть і щільність запасу сировини на облікових ділянках станом на 2014 р. не досягла значень 2010 р. Антропогенне навантаження в межах моніторингової площі зменшилося (сінокосіння відбувається переважно 1 раз на початку плодоношення A. montana). Збільшення кількості генеративних особин відбулося, ймовірно, за рахунок переходу дорослих вегетативних у генеративну стадію. Суттєво зменшилася кількість і частка особин арніки молодшої вікової групи $(j+i m)$, що могло статися внаслідок зростання проективного покриття переважно за рахунок збільшення участі конкурентоспроможних видів (Festuca rubra (45\%), Vaccinium myrtilus (10\%)) і затінення Picea abies.

Зміни у віковій структурі $A$. montana та ресурсній значущості відбуваються повільно. За високих показників рясності конкурентних видів створюються екстремальні умови для генеративного розмноження A. montana, однак велика кількість особин вегетативної групи є важливим резервом для реа- лізації ресурсної цінності ценопопуляції впродовж тривалого періоду.

Моніторингова площа №3 закладена за умов слабкого антропогенного навантаження (сінокосіння переважно один раз на рік). Угруповання характеризується багатим видовим різноманіттям (32 види судинних особин) за незначної участі злаків і високих показників проективного покриття (93\%). Найбільше тут представлені A. montana (20\%), Hypochoeris radicata L. (10\%), Festuca rubra (10\%), Luzula luzuloides (Lam.) Dandy \& Wilmott (10\%), Nardus stricta (5\%), Vaccinium myrtillus (5\%). Добре виражений моховий покрив (10\%). Початок цвітіння A. montana настає на день-два пізніше, ніж на попередній моніторинговій площі, що може бути зумовлене розміщенням МП №3 на 150 м вище, ніж МП №2, хоча відстань між ними - лише кілька кілометрів.

Ценопопуляція A. montana характеризується високою рясністю і життєвістю, лівобічним спектром. Частка передгенеративних особин становить $81 \%$ (таблиця). Частка генеративних особин низька (12,5 \%); кількість пагонів із трьома і більше суцвіттями удвічі перевищує кількість таких з одним суцвіттям, що позитивно позначається на ресурсних показниках. Збір сировини $A$. montana тут незначний (для власних потреб), оскільки ділянка розміщена в межах приватного угіддя. Сiнокосіння низькопродуктивне, тому здійснюється лише один раз, переважно в період масового цвітіння A. montana. Останнє є основним негативним чинником для розвитку ценопопуляції $A$. montana, тому що насіння не встигає визріти, а це загрожує іiі генеративному відновленню.

У 2011 р. тут мало зросла частка особин арніки наймолодшої групи та генеративних особин; на $5 \%$ знизилася частка вегетативних і на $2 \%$ - сенільних особин. Дещо збільшилася кількість генеративних особин із одним і трьома суцвіттями, але удвічі зменшилася з п'ятьма суцвіттями, тому кількість суцвіть загалом на облікових ділянках знизилася на $15 \%$. Такі зміни є в межах достовірної статистичної похибки, вони можуть бути зумовлені як внутрішньо популяційними чинниками, так і незначною зміною ценотичних і екологічних умов середовища.

Результати спостережень 2012 р. підтверджують флуктуаційний характер змін структури ценопопуляції A. montana за умов відсутності чітких індика- 
торів, лімітуючих чи стимулюючих ці зміни за короткий проміжок часу. Відчутно збільшилася кількість генеративних особин $A$. montana (таблиця), насамперед за рахунок таких із одним суцвіттям. Особливістю ценопопуляції є збільшення кількості генеративних пагонів, у яких третє суцвіття недорозвинене (7 шт.), що спостерігалося тут і в наступні роки. Це може свідчити про неспроможність повної реалізації ресурсного потенціалу рослинами в умовах нестачі ресурсів.

Показники щільності запасу сировини у 2012 р.

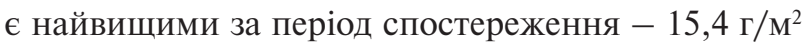

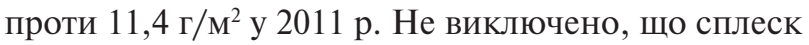
масового цвітіння арніки після періоду спокою $є$ закономірним явищем, властивим багатьом квітковим рослинам. Підтвердженням цієї думки можуть бути низькі показники щільності запасу сировини тут у наступний рік (2013) (таблиця). Відзначено, що кількість генеративних пагонів на облікових ділянках за рік майже не змінилася (50 проти 52 у 2012 р.), але кількість суцвіть зменшилася майже на 25 \%. Це спричинене збільшенням кількості пагонів із одним суцвіттям і зменшенням частки пагонів із багатьма суцвіттями. Тенденція до збільшення кількості особин $A$. montana з одним суцвіттям на дослідженій моніторинговій площі була стабільною впродовж усього періоду спостережень, а кількість особин із кількома суцвіттями та загальна їх кількість змінювалися щороку порізному.

За період спостережень на моніторинговій площі № 3 виявлено повільне зменшення загальної кількості особин $A$. montana (з 290 до 275 шт.) та частки особин вегетативної групи (з $81 \%$ у 2010 р. до $75 \%$ у 2014 р.). Кількість генеративних особин поступово збільшується (таблиця), але показники щільності запасу сировини щороку змінюються то в один, то в другий бік, оскільки вони тісно корелюють із кількістю суцвіть. Структура фітоценозу за досліджуваний період майже не змінилася. На ділянці спостерігається поступове збільшення участі злаків в угрупованні. Враховуючи повільні темпи динаміки, суттєві зміни тут можна буде виявити не раніше ніж через 5-7 років.

Моніторингова площадка № 4 закладена на вершині пологої гори. Травостій тут розріджений (75\%), на моніторинговій площі налічується 23 види судинних особин, із яких найряснішими є Festuca rubra (30\%), Nardus stricta (10\%), Arnica montana (7 \%), Thymus alpestris Tausch. (5\%). На ділянці наявне несистематичне (періодичне - 1-3 рази на тиждень) сильне пасовищне навантаження ( 4 особин великої рогатої худоби /га).

Ценопопуляція A. montana повночленна, характеризується лівобічним спектром. Частка іiі передгенеративних особин становить $79 \%$, генеративних - 7,2 \% (таблиця). Суттєве погіршення стану ценопопуляції виявлене на другий рік спостережень. Зокрема, майже на третину зменшилася кількість вегетативних особин і майже вдвічі - генеративних. Рослини перебували в пригніченому стані з механічним пошкодженням листків унаслідок витоптування худобою; висота генеративних пагонів зменшилася майже на $25 \%$. Сильне пасовищне навантаження протягом 2010-2011 рр. призвело до зниження частки молодих особин $(j, \mathrm{im}$, v) на $40 \%$, у т.ч. молодшої вікової групи - майже на $70 \%$. Це може свідчити про особливу чутливість молодих особин A. montana до ущільнення грунту та витоптування. Реакція на таке навантаження дорослих особин також виражена, але менше. Загальне проективне покриття травостою зменшилося на $15 \%$ переважно за рахунок зниження ролі злаків.

Відсутність пасовищного навантаження на третій рік спостережень позитивно позначилася на угрупованні загалом і відновленні арніки зокрема (таблиця). У 2012 році на моніторинговій площі сінокосіння було відсутнє у зв'язку з низькою якістю та повільним відновленням травостою, що сприяло розвиткові відновних процесів ценопопуляції A. montana. За незначного збільшення кількості вегетативних розеток у виду, кількість генеративних особин збільшилася вдвічі, переважно за рахунок таких з одним суцвіттям. Не виключено, що їхньому цвітінню раніше перешкоджало витоптування худобою. У 2013 р. сінокосіння в межах моніторингової площі здійснювалося двічі, співвідношення кількості особин різних вікових станів майже не змінилося (таблиця). Відновлення популяції загалом відбувається повільно, що може бути спричинене сінокосінням до повного достигання насіння арніки та інтенсивним збиранням суцвіть населенням для власних потреб.

У 2014 р. загальна кількість генеративних особин A. montana на облікових ділянках збільшилася порівняно з 2011 роком майже втричі, переважно за рахунок особин із одним суцвіттям. Тим часом кількість вегетативних розеток на п'ятий рік спос- 
тережень не досягла показників 2010 р., що може свідчити про повільне відновлення ценопопуляції після надмірного пасовищного навантаження. Частка особин наймолодшої вікової групи $(j+i m)$ станом на 2014 рік дорівнювала такій у 2010 р. Загалом у досліджуваній ценопопуляції $A$. montana загальна частка передгенеративних особин (j, $i m, v)$ становить близько $70 \%$ усіх рослин і залишається максимальною протягом усього періоду спостережень (таблиця). Частка генеративних особин упродовж періоду спостереження варіювала в межах 6-11\% із мінімальними показниками у 2011 р. Цвітіння арніки починалося майже одночасно, з різницею в 1-4 дні залежно від погодних умов поточного року.

При збереженні ступеня антропогенного навантаження (сінокосіння 1-2 рази на рік) можна очікувати поступового збільшення кількості генеративних особин A. montana внаслідок переходу в генеративну стадію вегетативних особин і зростання її ресурсних показників.

Моніторингова площадка № 5 закладена на території Карпатського біосферного заповідника. Пасовищне навантаження тут відсутнє, але періодично буває сінокосіння. Угруповання вирізняється високим загальним проективним покриттям травостою (95\%), видове різноманіття - 20 видів судинних особин, моховий покрив виражений слабо. У травостої найбільше представлені Festuca rubra (22\%), Arnica montana (20\%), Nardus stricta (15\%), Briza media L. (10\%), Luzula sylvatica (Huds.) Gaudin (10\%), Agrostis capillaris L. (5\%).

Популяція $A$. montana повночленна, характеризується лівобічним спектром із переважанням вегетативних особин (69 \%) (таблиця). Серед генеративних особин (17\%) дві третини становлять такі з трьома і більше суцвіттями. Частка особин молодшої вікової групи незначна $(7,8$ \%), що характерно для угруповань із високими показниками проективного покриття травостою, де формуються екстремальні умови для проростання насіння A. montana і виживання проростків за умов високої ценотичної конкуренції. Тут виявлені найвищі показники щільності запасу сировини $(21,2$ г/м²) 3 усіх моніторингових площ.

У 2011 р. на облікових ділянках мало змінилося співвідношення вікових груп A. montana (таблиця). Суттєво збільшилася лише частка генеративних особин за рахунок переходу вегетативних особин у генеративну стадію, однак загальна кількість суцвіть зменшилася. Зміна показника кількості суцвіть на облікових ділянках за період спостережень має флуктуаційний характер. Це може бути зумовлене як внутрішньопопуляційними чинниками, так і непередбачуваним негативним впливом температурного режиму в період розвитку рослин.

Зміни структури ценопопуляції A. montana та структури фітоценозу на моніторинговий період мало помітні: дешо збільшилася кількість Festuca rubra, Luzula sylvatica, Potentilla erecta; зменшилася - Briza media й Agrostis capillaris. Проективне покриття A. montana збільшилося, насамперед, за рахунок розростання розеток і незначного збільшення кількості особин на облікових ділянках (переважно - генеративних) (таблиця). Станом на 5 червня 2014 року на облікових ділянках кількість генеративних пагонів зросла порівняно з 2010 р. на 14 шт., але кількість суцвіть і щільність запасу зменшилася. Такі зміни можуть відбуватися за нестачі ресурсів для формування пагонів із багатьма суцвіттями.

За відсутності суттєвого впливу будь-якого негативного чинника на угруповання можна передбачити, що в подальшому буде зменшуватися у фітоценозі кількість видів різнотрав'я (у т.ч. A. montana) при збільшенні злаків і поступово знижуватиметься ресурсна значимість арніки. Враховуючи повільні темпи динаміки, суттєві зміни тут можливі лише через 7-10 років.

Моніторингова площадка №6 закладена за умов інтенсивного пасовищного навантаження (25 голів великої рогатої худоби на 4 га). У 2010 році проективне покриття рослинності тут становило $81 \%$. На моніторинговій площі налічується 28 видів судинних рослин із найбільшою представленістю Festuca rubra (25\%), Briza media (12\%), Nardus stricta (8\%) i Luzula luzuloides (7 \%); моховий покрив становить близько $15 \%$, проективне покриття $A$. montana - 7 \%. На цій моніторинговій площі початок іiї цвітіння візначено пізніше, ніж на інших площах (за винятком МП №7), на 6 днів.

У базовому спектрі ценопопуляції $A$. montana наявні всі онтогенетичні групи. Станом на 12 червня віргінільні та молоді генеративні рослини становлять близько 80 \% (таблиця). Причому частка особин молодшої вікової групи майже вдвічі перевищує таку генеративної групи. Це співвідношення можна пояснити наявністю ділянок із поруше- 
ним природним рослинним покривом, де може проростати насіння, однак більшість проростків і ювенільних рослин гинуть протягом літа безпосередньо від витоптування худобою.

На 10 облікових ділянках моніторингової площі налічується 20 генеративних особин $A$. montana. Майже всі вони перебувають у пригніченому стані, з пошкодженим листям. Серед генеративних особин більше половини мають по три і більше суцвіть, на багатьох рослинах окремі суцвіття недорозвинені або пошкоджені. Показник щільності запасу сировини сягає 46 кг/га.

Високий ступінь пасовищного навантаження у межах спостережень зберігався впродовж усіх наступних років (включно по 2014), що призвело до виснаження ценопопуляції A. montana. За період спостережень зменшилося загальне проективне покриття травостою до $70 \%$, ценопопуляцію A. montana поступово все глибше охоплювали дигресивні процеси. Пасовищне навантаження тут то збільшувалося, то зменшувалось, але було значним, що негативно позначилося на угрупованні загалом і на стані та структурі ценопопуляції $A$. montana. Знизилося проективне покриття арніки, в розетках зменшилася кількість і розміри листків; на облікових ділянках відчутно знизилася частка усіх вікових груп арніки, за винятком сенільних (таблиця). Середні показники висоти особин практично не змінилися. Кількість генеративних особин зменшилася майже вдвічі, суцвіть - утричі. На облікових ділянках майже всі особини арніки сформували по одному суцвіттю.

Низька регенераційна здатність популяцій A. montana, ймовірно, визначається тим, що вона належить до видів, які не поїдаються чи мало поїдаються копитними тваринами. Тому в ході еволюції біоценозів арніки не появилася здатність швидко відростати, як у лучних злаків. За цією ознакою можна більш-менш упевнено прогнозувати негативну динаміку досліджуваної ценопопуляції A. montana в найближчі 5-10 років. Вона, як свідчать результати моніторингу на моніторингових площадках № 1 та № 2, добре пристосована до слабших навантажень.

Моніторингова площадка №7 закладена за умов відсутності вираженого антропогенного навантаження. Угруповання характеризується високим проективним покриття травостою (близько $100 \%$ ) та високою рясністю злаків: Festuca rubra (30\%),
Nardus stricta (10\%), Anthoxanthum alpinum A. Löve \& D. Löve (5 \%), Briza media (3\%). Загалом тут налічується 30 видів трав'янистих рослин. Серед різнотрав'я найбільше поширені: A. montana (5\%), Potentilla erecta (3\%), Hypochoeris radicata (2\%). Мохово-лишайниковий ярус виражений слабо. На площі є молоді рослини Betula pendula L. i Rubus plicatus Weihe \& Nees.

Особливістю вікової структури ценопопуляції A. montana є мала частка особин $(7,1 \%)$ молодшої вікової групи $(j+i m)$ і сенільних особин $(4,9 \%)$. Три чверті становлять вегетативні особини й лише 12,2\% - генеративні (таблиця). Таке співвідношення різних вікових груп ценопопуляції A. montana зумовлене, насамперед, високим ступенем ценотичної конкуренції, оскільки для проростання насіння та розвитку особин $A$. montana на початковій стадії онтогенезу потрібна наявність вільного життєвого простору, що неможливо в умовах щільного травостою. Вегетативні особини вже зайняли своє місце в угрупованні; вони витривалі за умов обмежених ресурсів середовища, часто є раметами з добре розвиненим кореневищем, тому здатні витримувати конкурентний вплив із боку інших трав'янистих видів і зберігати свою роль у фітоценозі тривалий час.

Зміни структури фітоценозу та ценопопуляції $A$. montana в наступні роки спостережень мали флуктуаційний характер або були слабо виражені. Відзначене стабільне збільшення в фітоценозі ролі злаків, а також участі Rubus plicatus i Betula pendula. У віковій структурі ценопопуляції A. montana суттєво зменшилася частка особин молодшої вікової групи (до 4,5 \% із 7,1); мало знизилася загальна кількість особин арніки та кількість генеративних і сенільних особин, а також дещо збільшилася - вегетативних (таблиця).

Найвідчутніше змінилися за період спостережень показники щільності запасу сировини (з 62,1 до 29,9 г/10 м²), що зумовлено зменшенням кількості генеративних пагонів A. montana 3 трьома i більше суцвіттями. Ймовірно, такі зміни є результатом ценотичної конкуренції за ресурси середовища. За високої ценотичної конкуренції створюються екстремальні умови як для проростання насіння арніки, так і наявна нестача ресурсів для формування генеративних пагонів із багатьма суцвіттями. 
Загалом динаміка вікової структури ценопопуляції A. montana на даній моніторинговій площі за п’ять років мало помітна, на відміну від ресурсних показників, оскільки природні зміни лучних фітоценозів - тривалий процес. Нестача ресурсів середовища знайшла, насамперед, відображення на зменшенні ресурсної значущості ценопопуляції арніки за період, що підтверджує індикаторну значущість ресурсних показників у сукцесіях популяцій трав'янистих особин.

\section{Висновки}

Пасовищне навантаження - найбільше виражений негативний фактор, який за короткі терміни спричиняє дигресивні зміни ценопопуляцій A. montana на території Українських Карпат. Зменшення чи припинення такого навантаження зумовлює активізацію відновних процесів ценопопуляції, зокрема цвітіння $A$. montana.

Сінокосіння знижує лімітуючий вплив конкурентоспроможних видів рослин на популяції A. montana, а водночас перешкоджає ії насіннєвому поновленню, оскільки здійснюється переважно до визрівання насіння. Ресурсна значущість A. montana в умовах сінокосіння тривалий час може зберігатися за рахунок активізації вегетативного розмноження.

За умов обмеженого антропогенного навантаження зміни у віковій структурі A. montana та ресурсній іiі значущості перебігають повільно. За високих показників рясності конкурентних видів створюються екстремальні умови для іiї генеративного розмноження, однак велика кількість особин вегетативної групи є важливим резервом для реалізації ресурсної цінності ценопопуляції впродовж тривалого періоду. У сформованому фітоценозі перехід рослин $A$. montana 3 вегетативної стадії до генеративної поступово уповільнюється, оскільки для генеративних рослин потрібно більше ресурсів, ніж для вегетативних, а ценотична конкуренція зростає.

Неконтрольований збір суцвіть A. montana для власних потреб чи реалізації зменшує можливість генеративного розмноження виду.
Для зниження загрози дигресії популяцій A. montana в Українських Карпатах конче потрібно повернути їй статус охорони на державному рівні.

\section{СПИСОК ЛІТЕРАТУРИ}

Hamilton A., Durbeck K., Lawrence A. Towards a sustainable herbal harvest // Plant Talk. - 2006. - 43. - P. 32-35.

Kahmen S., Poschlod P. Population size, plant performance, and genetic variation in the rare plant Arnica montana L. in the Rhön, Germany // Basic and Applied Ecology. - 2000. - 1(1). - P. 43-51.

Kathe $W$. Conservation of Eastern European medicinal plants: Arnica montana in Romania // Medicinal and Aromatic Plants Agricultural, Commercial, Ecological, Legal, Pharmacological and Social Aspects Series: Wageningen UR Frontis Series, Vol. 17. - J. B. Robert, L.E. Craker; D. Lange (Eds.). - 2006, XVIII. - 309 p.

Kathe W., Honnef S., Heym A. Medicinal and aromatic plants in Albania, Bosnia-Herzegovina, Bulgaria, Croatia and Romania. - Bonn, Germany, 2003. - 200 p.

Kobiv Iu.I. Populiatsii ridkisnykh vydiv Ukrainskykh Karpat: struktura, dynamika, zberezhennia: Avtoref. dys. ... dokt. biol. nauk: 03.00.05, UDU. - Kyiv, 2014. - 42 p. [Кобів Ю.Й. Популяції рідкісних видів Українських Карпат: структура, динаміка, збереження: Автореф. дис. ... докт. біол. наук: 03.00.05 / УДУ. - К., 2014. 42 c. ].

Kyiak V., 2007. - Nauk. zap. derzhavn. pryrodoznavchoho muzeiu. - Lviv. - Vyp. 23. - P. 31-42 [Кияк В. Особливості сусідства, асоційованості і взаємовпливу між популяціями рідкісних видів рослин у високогір"ї Карпат// Наук. зап. державн. природознавчого музею. - Львів, 2007. - Вип. 23. - С. 31-42].

Parolo G., Rossi G., Ferrarini A. Toward improved species niche modelling: Arnica montana in the Alps as a case study // J. Appl. Ecol. - 2008. - 45. - P. 1410-1417.

Minarchenko V.M., Tymchenko I.A., Hlushchenko L.A., Syvohlaz L.M., 2008. - Ahroekol. zhurn. - № 3. P. 32-36 [Мінарченко В.М., Тимченко І.А., Глущенко Л.А., Сивоглаз Л.М. Методичні аспекти моніторингу недеревних рослинних ресурсів // Агроекол. журн. - 2008. - № 3. - С. 32-36].

Rabotnov T.A., 1988. - Ekologiia. - № 2. - P. 5 [Работнов T.A. Структура и методика изучения ценотических популяций многолетних травянистых растений / Экология. - 1988. - № 2. - С. 5].

Red list IUCN (2013/2). http:// www.iucnredlist.org/

Uranov A.A., 1975. - Biol. nauki. - № 2. - P. 7-34. [Уpaнов А.A. Возрастной спектр фитоценопопуляций как функция времени и энергетических волновых процессов / Биол. науки. - 1975. - № 2. - С. 7-34].

Рекомендує до друку

Надійшла 28.01.2015 p. 
Вантюх И.В. Мониторинг ресурсов Arnica montana (Asteraceae) на территории Украинских Карпат. - Укр. ботан. журн. - 2015. - 72(2): 135-143.

Институт ботаники имени Н.Г. Холодного НАН Украины, г. Киев

Рассмотрены результаты пятилетних наблюдений за динамикой структуры и ресурсной значимостью ценопопуляций Arnica montana L. на семи мониторинговых площадях в различных регионах Карпат. Изучено влияние сенокошения и пастбищной нагрузки на состояние и динамику ее ресурсов. Установлено, что наиболее выраженным лимитирующим фактором для ресурсной значимости ценопопуляций $A$. montana является пастбищная нагрузка на ее биотопы. В условиях ограниченной антропогенной нагрузки изменения у возрастной структуре популяций A. montana и еe ресурсной значимости проходят медленно и определяются степенью ценотической конкуренции.

Ключев в е слова: Arnica montana, мониторинг, ресурсы, антропогенное влияние.
Vantjuh I.V. The monitoring of resources of Arnica montana L. (Asteraceae) in the Ukrainian Carpathians. - Ukr. Bot. J. - 2015. - 72(2): 135-143.

M.G. Kholodny Institute of Botany, National Academy of Sciences of Ukraine, Kyiv

The results of five-year observations of the dynamics and structure of coenotic populations and resource significance of Arnica montana L. on 7 monitoring areas in different regions of the Carpathians are reported. The effect of mowing and grazing pressure on the state and dynamics of the resources of arnica were studied. It hes been found that the most severe limiting factor for resource significance of coenotic populations of $A$. montana is the grazing pressure on the habitats. Under conditions of restricted anthropogenic load, changes in the age structure of populations of $A$. montana and its resource significance were slow and determined by the degree of coenotic competition.

Ke y words: Arnica montana, monitoring, resources, anthropogenic impact. 